\title{
Wpływ kryzysu na wielkość pasażerskiego ruchu lotniczego na świecie na podstawie wybranych przykładów
}

Skomplikowany system gospodarczy współczesnego świata jest bardzo wrażliwym układem wspólnych powiązań systemowych i funkcjonalnych. Dlatego też kryzysy ekonomiczne są odczuwalne w różnych sektorach gospodarczej działalności człowieka oraz w różnych regionach świata. Przykładem sektora, który odczuł pośrednie skutki ostatniego kryzysu finansowego na świecie, jest transport lotniczy. Ogólnoświatowy kryzys finansowy spowodował zmniejszenie liczby pasażerów korzystających z tego rodzaju transportu oraz wzrost cen paliw na rynkach światowych zwiększających koszty operowania. Rozważania na temat wpływu kryzysu ekonomicznego na wielkość ruchu pasażerskiego wybranych linii lotniczych omówiono na podstawie danych przewozowych dużych przewoźników lotniczych z różnych części świata i prezentujących dwa odmienne modele operowania (linie tradycyjne i typu low cost). Rynek europejski reprezentuje Lufthansa - największy przewoźnik europejski oraz jeden z jego największych rywali, British Airways. Z kontynentu północnoamerykańskiego wybrano dwie wiodące linie lotnicze: American Airlines oraz Continental Airlines, które po połączeniu z innym „flagowcem” amerykańskim (United Airlines) stworzyły w $2010 \mathrm{r}$. największą na świecie pod względem liczby maszyn spółkę lotniczych przewozów pasażerskich, dysponującą flotą blisko 1000 statków powietrznych. Z rynku południowoamerykańskiego uwzględniono dane chilijskich narodowych linii lotniczych LAN, jednego z największych przewoźników w tej części świata. Singapore Airlines, uznaną za jedną z najlepszych linii lotniczych pod względem jakości świadczonych usług, posłużono się jako przykładem w celu zaprezentowania rynku przewozów pasażerskich na kontynencie azjatyckim. Grupę przewoźników działających według modelu typu low cost omówiono na podstawie danych niemieckiej spółki Germanwings.

\section{WIELKOŚĆ PASAŻERSKIEGO RUCHU POWIETRZNEGO W WYBRANYCH PORTACH LOTNICZYCH ŚWIATA}

Na ryc. 1 przedstawiono zmiany wielkości ruchu pasażerskiego w wybranych portach lotniczych świata w latach 2007-2010. Wybrano następujące porty: amerykański węzeł lotniczy Atlanta Hartsfield, od kilku lat z rzędu przyjmujący największą w skali globalnej liczbę pasażerów, Londyn Heathrow - największy port lotniczy Europy oraz niemiecki Frankfurt 
International - znany z największej na świecie liczby destynacji międzynarodowych. We wszystkich trzech przypadkach zaobserwowano sezonowość ruchu pasażerskiego, warto jednak porównać zmiany wielkości przewozów w poszczególnych sezonach: zimowym i letnim w kolejnych latach. W przypadku Atlanty najniższe obciążenie portu zanotowano w miesiącach styczeń i luty. W pierwszym miesiącu 2007 r. lotnisko obsłużyło 6,4 mln pasażerów, rok później - 6,6 mln. Początek roku 2009 zakończono również ze zwiększoną o 2\% (do 6,8 mln) liczbą pasażerów, podczas gdy w styczniu 2010 r. odnotowano spadek wielkości ruchu. Nieprzerwany spadek liczby osób korzystających z usług portu obserwowano począwszy od czerwca 2008 r. aż do lutego 2010 r. (z niewielkimi wzrostami, które odnotowano w styczniu i wrześniu 2009 r.). Luty 2010 r. to dla stolicy amerykańskiego stanu Georgia najmniejsza liczba osób (niespełna $6 \mathrm{mln}$ ) korzystających z tego ważnego HUB-u w całym omawianym okresie. Podsumowując dane dotyczące całego okresu ogółem, najsłabsze wyniki port lotniczy osiaggnął w 2008 roku (spadek o 2,2\%). W przeciagu lat 2007-2009 port lotniczy stracił łącznie blisko 1,4 mln pasażerów (przy równoczesnym spadku operacji lotniczych).

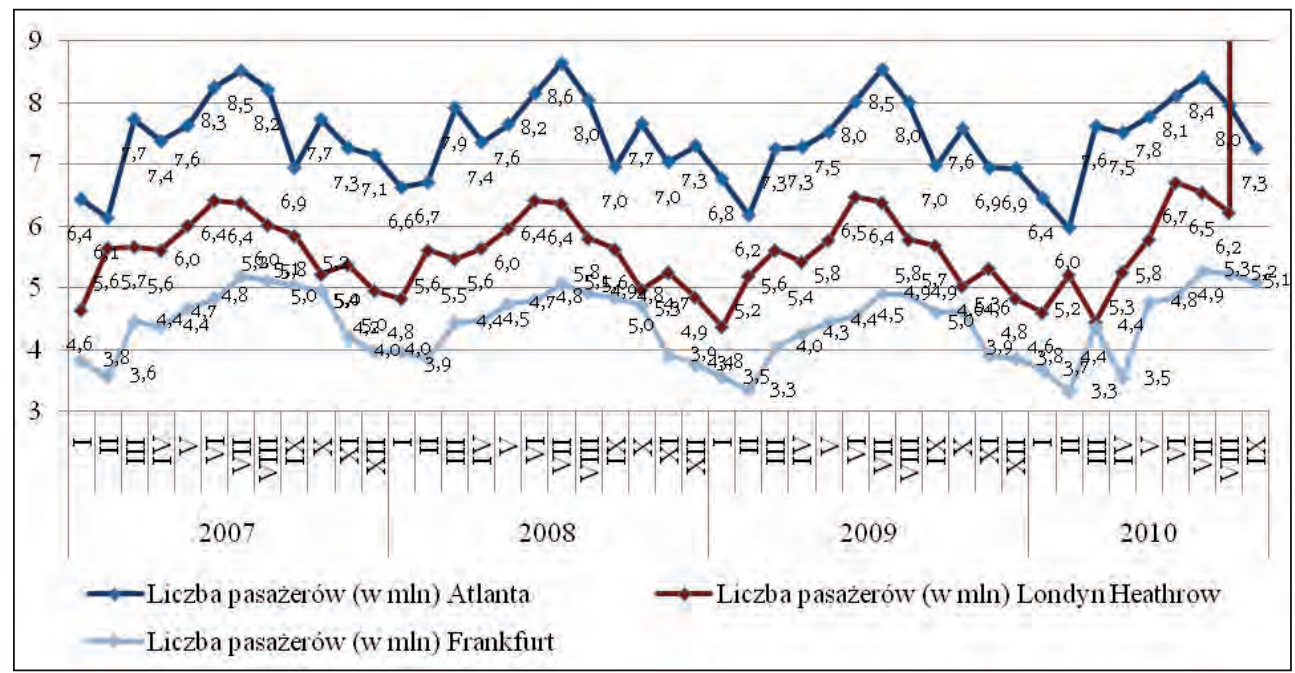

Ryc. 1. Liczba pasażerów i operacji lotniczych wybranych portów lotniczych świata w latach 2007-2010 (w mln)

Źródło: opracowanie własne na podstawie: World Airport Traffic Report, 2007, Airports Council International

Nieco odmienna sytuacja miała miejsce w podlondyńskim Heathrow. Najważniejsze lotnisko Europy odnotowało spadki liczby podróżnych już w pierwszej połowie 2007 roku, jednak całoroczny wynik utrzymano na poziomie roku poprzedniego, osiągając niewielki wzrost. Rok 2008 został zakończony stratą jedynie luty przyniósł dość znaczny (4\%) wzrost liczby przyjętych pasażerów. Podobnie jak w Atlancie, również i tu najgorsze wyniki osiągnięto w 2009 r., kiedy to odnotowano zmniejszony o 1,5\% ruch pasażerski. W lutym tego roku obsłużono najmniej pasażerów w całym okresie poddanym analizie (niespełna $4 \mathrm{mln}$ ). W latach 2007-2009 brytyjskie Heathrow straciło łącznie 1,9 mln klientów korzystających z usług podniebnych przewoźników. Rok 2010 powinien okazać się dla lotniska korzystny 
mimo gwałtownego załamania ruchu pasażerskiego w kwietniu w związku z wybuchem wulkanu na Islandii.

Niemiecki Frankfurt mimo dobrych wyników za 2007 rok (wzrost podróżnych o 2,6\%) nie oparł się kryzysowi w branży i z początkiem sezonu letniego 2007 zaczął notować stałe spadki liczby podróżnych aż do listopada 2009 roku. Również i tu największą stratę obserwowano podsumowując 2009 rok - zmniejszenie pasażerów o 4,7\%. Najsłabszy wynik osiaggnięto zimą 2009 r. (luty: 3,3 mln pasażerów, spadek aż o 13,3\%). W latach 2007-2009 metropolia położona nad Menem przyjęła łącznie aż o 3,2 mln mniej pasażerów kompanii lotniczych. Również i w tym przypadku dane za rok 2010 wykazują pozytywną tendencję. Wrzesień tego roku to największy w całym okresie wzrost liczby podróżujących (aż o $10 \%$ ).

\section{WIELKOŚĆ PASAŻERSKIEGO RUCHU POWIETRZNEGO W WYBRANYCH LINIACH LOTNICZYCH ŚWIATA}

Rycina 2 przedstawia wielkość ruchu pasażerskiego w wybranych kompaniach lotniczych. Z rynku północnoamerykańskiego poddano analizie dane przewozowe dwóch wielkich flagowców: American i Continental Airlines. Wyniki obu przewoźników są dość zbieżne. Obydwie linie zanotowały wzrost liczby obsłużonych pasażerów w 2007 r. (mimo niekorzystnych statystyk w AA w pierwszej połowie roku). Kolejne lata to pogłębiający się kryzys i spadek liczby podróżujących. W obu przypadkach najgorszy w tym względzie był rok 2009. American Airlines obsłużył w tym czasie aż o 7,6\% mniej pasażerów, przy spadku Continentala o 5,8\%. W przeciagu lat 2007-2009 AA stracił aż 12,4 mln swoich klientów, podczas gdy CA 6,1 mln podróżnych. Rok 2010 przyniósł obu firmom spowolnienie dynamiki spadkowej lub niewielkie wzrosty w poszczególnych miesiącach.

Nieco odmienna sytuacja miała miejsce w dwóch największych liniach lotniczych Europy - British Airways i Lufthansie. W przypadku brytyjskiego przewoźnika na kłopoty związane z kryzysem nałożyły się problemy związane przede wszystkim ze strajkami kadry pracowniczej. 2007 rok przyniósł BA spadek liczby pasażerów aż o 7,3\% w porównaniu do roku poprzedniego. Notowania spadkowe towarzyszyły flagowcowi przez cały rok 2008, ale w przeciwieństwie do większości przytoczonych przykładów w 2009 roku linia odnotowała niewielki wzrost liczby pasażerów (o $0,2 \%$ ). Lufthansa natomiast osiagnęła bardzo dobre wyniki w 2007 roku, zdobywając nowych pasażerów (5,6\%), podobnie było rok później, kiedy to uzyskano ogólny roczny wynik ,na plusie”. Mimo to począwszy od lipca 2008 aż do czerwca 2009 roku liczba pasażerów przewoźnika spadała. Rok 2009 Lufthansa zakończyła z ogólnym spadkiem liczby klientów, którzy skorzystali z usług firmy. Na przełomie lat 2007-2009 obydwie wymienione linie straciły pasażerów: BA $1 \mathrm{mln}$, natomiast Lufthansa $0,8 \mathrm{mln}$. Rok 2010 niemieckiemu flagowcowi powinien przynieść pozytywne zmiany w wielkości przewozów (doskonałe wyniki za wrzesień), natomiast w przypadku brytyjskich narodowych linii nadal obserwowano recesję (bardzo słaby sezon wiosenno-letni). 


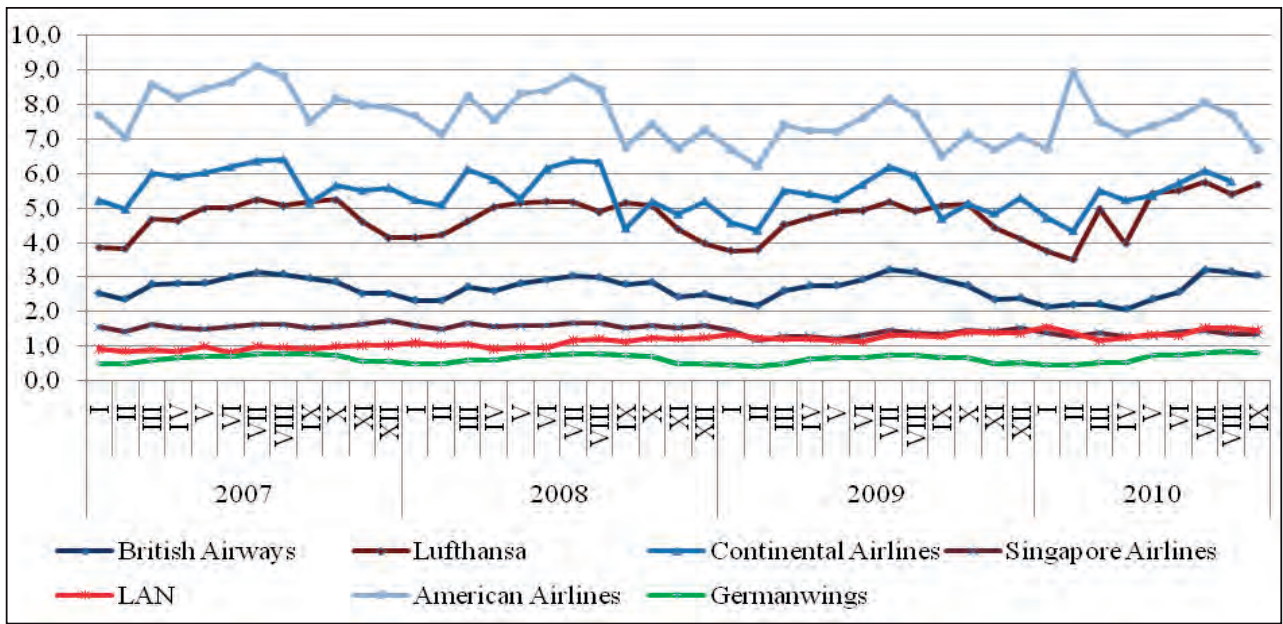

Ryc. 2. Liczba pasażerów wybranych linii lotniczych w latach 2007-2010 (w mln) tional

Źródło: opracowanie własne na podstawie: World Airport Traffic Report, 2007, Airports Council Interna-

Wielkość przewozów pasażerskich na rynku azjatyckim zaprezentowano na podstawie wyników przewozowych ważnego azjatyckiego flagowca - Singapore Airlines - znanego na świecie przede wszystkim z doskonałej jakości oferowanych usług. 2007 rok omawiana linia zakończyła, osiagając 5,2\% wzrost liczby przewiezionych pasażerów. W 2008 r. odnotowano spowolnienie przyrostu liczby pasażerów, aż do listopada, kiedy to przez 15 kolejnych miesięcy obserwowano spadki liczby przewiezionych klientów. Najgorsze okazały się marzec i maj 2009 r. - ponad 23\% mniej pasażerów w porównaniu z rokiem poprzednim. Wynik narodowych linii Singapuru za 2009 r. to spadek wielkości przewozów o 14,7\%. Na przestrzeni lat 2007-2009 z podróży samolotem w barwach SA skorzystało w sumie 2,6 mln mniej podróżnych. Rok 2010 dla przewoźnika oznacza wyjście z recesji i zwiększenie ruchu.

Wśród wybranych przewoźników w opracowaniu znalazł się również południowoamerykański LAN, który jako jedyny z omawianych przykładów oparł się kryzysowi ekonomicznemu w branży i w okresie poddanym analizie stale notował wzrost liczby pasażerów często sięgający powyżej 20\%. Najbardziej pomyślny dla przewoźnika był rok 2007 - blisko 25\% wzrost liczby pasażerów. Rok 2009, w którym większość linii lotniczych borykała się z poważnymi problemami, dla chilijskiego flagowca oznaczał jedynie spowolnienie (i tak wysokiego) wzrostu (do 16,4\%). W latach 2007-2009 LAN jako jedyny z omawianych przewoźników zyskał nowych pasażerów $(4,3 \mathrm{mln})$, co przekłada się na blisko $40 \%$ wzrost. W roku 2010 w kompanii obserwowano dalsze zwiększenie wielkości przewozów (mimo słabszego marca i kwietnia).

Jako ostatnie poddane analizie zostały „tanie linie lotnicze” Germanwings, należące do Grupy Lufthansa. Cały 2007 r. to dla niemieckich linii ciagłe wzrosty liczby pasażerów (najlepsze miesiące to lipiec i sierpień). Podobnie jak w przypadku większości tradycyjnych przewoźników, również Germanwings dotknął kryzys ekonomiczny. Najgorsze wyniki odnotował w 2009 roku, który przyniósł 6\% spadek liczby podróżnych. Łącznie w latach 2007-2009 linie utraciły 700 tys. pasażerów, jednak w 2010 r. przewoźnik notuje ponownie 
wzrost liczby korzystających z jego usług (za wyjątkiem kwietniowego ogólnoeuropejskiego paraliżu w ruchu lotniczym).

\section{SPOSOBY WALKI Z KRYZYSEM EKONOMICZNYM}

W PASAŻERSKICH LINIACH LOTNICZYCH - STUDIUM PRZYPADKU

Linie lotnicze podjęły szereg działań związanych z przywróceniem odpowiedniej wielkości ruchu pasażerskiego, a tym samym większej rentowności. Do najważniejszych należą połączenia przewoźników, w tym również tych największych i najbardziej znanych na świecie kompanii, niejednokrotnie chroniąc je przed bankructwem. Pierwszą dużą fuzją ostatnich lat było połączenie w 2004 r. dwóch dużych europejskich linii: holenderskiego KLM oraz francuskiego Air France. Obydwaj „flagowcy” zachowali swoje marki i operują pod własnymi nazwami. W 2010 r. holding ogłosił włączenie do grupy innego holenderskiego przewoźnika: Martinair. Największa linia lotnicza Europy - niemiecka Lufthansa - umacniając swoją pozycję na rynku „przejęła” w ostatnich latach w całości kilku przewoźników: szwajcarskiego Swiss, brytyjskie linie BMI (British Midland International) oraz austriackie narodowe Austrian Airlines. Ostatnia głośna fuzja na rynku europejskim to połączenie British Airways oraz hiszpańskiej Iberii. Fuzje przewoźników nie są domeną linii tylko z naszego kontynentu. W 2010 r. władze USA zezwoliły na „zjednoczenie” dwóch amerykańskich gigantów: Continental i United Airlines. Cały proces potrwa do roku 2012 i pozwoli na oszczędności szacowane na 1 bln USD rocznie. Dwie dobrze znane na kontynencie południowoamerykańskim linie LAN (Chile) oraz TAM (Brazylia) również postanowiły połączyć swoje siły i rozpocząć wspólną działalność pod nazwą LATAM.

Ważnym zagadnieniem dotyczącym współpracy pomiędzy poszczególnymi liniami są alianse strategiczne. Na świecie największą rolę odgrywają: Star Alliance, One World oraz Sky Team. Głównymi założycielami wymienionych sojuszy jest trzech największych konkurentów na kontynencie europejskim: odpowiednio Lufthansa, British Airways oraz Air France. Alians strategiczny wzmacnia pozycję współpracujących ze sobą linii lotniczych wobec silniejszych konkurentów (dwie dotychczas słabsze firmy stają się silniejsze po dokonaniu aliansu). Jest to związek między przewoźnikami lotniczymi, których zamierzeniem jest realizowanie przez partnerów strategicznych wspólnego celu, włączając wspólną sieć planowania, wspólną politykę cenową i wspólne budżetowanie, wzajemny program frequent flyer, code sharing. Uogólniając, zawieranie aliansów ma wzajemne korzyści dla przewoźników: zdobycie nowego rynku zbytu, chęć uratowania przedsiębiorstwa będącego w trudnej sytuacji finansowej, ograniczenie kosztów reklamy, ograniczenie ryzyka finansowego, zdobycie nowej wiedzy, wymiana pracowników i praktykantów, ochrona przed przejęciem. Głównym celem każdego z sojuszy jest przyciągnięcie i utrzymanie pasażerów często podróżujących na dalekich dystansach, co oznacza przede wszystkim wysokopłatny ruch biznesowy i zagwarantowanie pasażerom jednolitego standardu na całej trasie (Radomyski 2009, s. 29). Szczególną aktywność w przystępowaniu do aliansów strategicznych obserwujemy w ostatnich latach, a włączenie japońskich linii lotniczych JAL do sojuszu One World było jednym z elementów obrony przewoźnika przed bankructwem. Korzyści ze współpracy strategicznej pomiędzy przewoźnikami są dwustronne. Dla pasażera oznacza to przede wszystkim dostępność korzystniejszych taryf, a co za tym idzie większej liczby połączeń w bardziej przystępnym rozkładzie połączeń oraz dostępność ofert typu round the world. 
Podniesienie jakości oferowanych usług jest istotnym sposobem na zatrzymanie oraz pozyskanie pasażera. Jednym z najważniejszych elementów podnoszenia jakości, szczególnie ważnym dla każdego przewoźnika, jest unowocześnianie floty. Pomaga to w rozwoju linii oraz zagwarantowaniu odpowiedniego standardu oferowanych usług. W tym przypadku przewoźnicy są poniekąd uzależnieni od dostawców samolotów ze względu na dość długi okres oczekiwania i złożony proces produkcji samolotów. Dwóch największych graczy na globalnym rynku producentów samolotów - amerykański Boeing oraz europejskie konsorcjum Airbus - skutecznie opóźniło plany rozwoju wielu liniom lotniczym na całym świecie ze względu na problemy w realizacji dwóch pionierskich projektów: Boeinga 787 oraz Airbusa A380. Europejskie „Super Jumbo” wprowadzone do eksploatacji w 2007 r. w singapurskich liniach lotniczych Singapore Airlines może przyjąć na swój pokład (a w zasadzie dwa pokłady) ok. 500 pasażerów w 3-klasowej konfiguracji lub nawet 800 osób przy rezygnacji z komfortu pasażerów na rzecz większej liczby miejsc w samolocie. Większy samolot oznacza mniejsze koszty operowania oraz większą zyskowność na bardziej popularnych, dalekodystansowych połączeniach. Znacznie wydłużona niż pierwotnie zakładano realizacja projektu „liniowca marzeń” - Boeinga 787 - pokrzyżowała plany wielu światowym operatorom lotniczym, w tym rodzimego LOT-u. Dla stosunkowo niedużej linii jaką jest polski przewoźnik oznacza to kilkuletnią blokadę wymiany dalekodystansowej floty oraz rozwoju siatki połączeń międzykontynentalnych.

Reorganizacja modelu funkcjonowania to także sposób na obniżenie kosztów i wygenerowanie większych zysków. Brytyjskie linie Monarch, obsługujące głównie destynacje wakacyjne, zrezygnowały w ostatnim czasie z darmowych dodatków typowych dla flagowców (bagaż w cenie biletu, serwis na pokładzie). Przewoźnik wprowadził charakterystyczne dla low-costów opłaty za bagaż, serwis na pokładzie oraz miejsca ze zwiększoną przestrzenią na nogi. Inny przykład reorganizacji świadczonych usług, będący przykładem odpowiedzi na nowe potrzeby rynku, to powiększenie klasy ekonomicznej w samolotach linii Qantas kosztem przestrzeni klasy biznes.

Rezultatem trudnych lat kryzysu w branży są zmiany w siatce połączeń przewoźników i likwidacja nierentownych połączeń. W ciagu kilku minionych lat trzech przewoźników europejskich zamknęło swoje wszystkie długodystansowe połączenia. Większość dalekich połączeń Austrian Airlines obejmowała loty do Azji Południowej i Południowo-Wschodniej oraz tzw. „trasę kangurową” z Wiednia przez Singapur do Australii. W 2007 r. węgierski Malev ogłosił rezygnację z operacji na trasach transatlantyckich do Toronto i Nowego Jorku. W chwili obecnej przewoźnik nie posiada żadnych maszyn mogących latać na lotach dalekiego zasięgu. Podobnie uczyniono w przypadku siatki połączeń Czech Airlines. Na rodzimym rynku pasażerskich przewozów lotniczych z ostrym protestem wielu środowisk spotkało się usunięcie z rozkładu lotów trasy Kraków-Chicago i Nowy Jork dostępnej dla pasażerów z południowej Polski przez 13 lat (Boeinga 767 wykorzystywanego do obsługi tej trasy przekierowano do nowo powstałego połączenia Warszawa-Hanoi). Z lotnisk regionalnych w Krakowie oraz Poznaniu wycofał się również British Airways, rezygnując z operowania do Londynu Gatwick. Innym typem reorganizacji siatki połączeń jest „,przekazanie” mniej opłacalnych tras do firm-córek. Tak było np. w przypadku Singapore Airlines, notującej znaczne spadki liczby pasażerów. Firma przekazała siostrzanej linii SilkAir kilka ze swoich regionalnych tras.

Kryzys ekonomiczny razem z polityką otwartego nieba spowodował jeszcze większą walkę o pasażera i zaciętą ,wojnę cenową". Na rynku azjatyckim przykład ostrej konku- 
rencji jest obserwowany na krótkiej trasie Kuala Lumpur-Singapur, która z racji swojego obciążenia jest czwartym najbardziej popularnym wśród pasażerów połączeniem lotniczym na kontynencie. Dopuszczenie niskokosztowych przewoźników do operacji na omawianej trasie (która do tej pory obsługiwana była przede wszystkim przez narodowe linie Singapuru i Malezji) doprowadziło do drastycznego spadku udziału w rynku tradycyjnych linii oraz obniżenie cen biletów. Przewoźnicy niskokosztowi, wykorzystując trudną sytuację w branży, wywierają presję na porty lotnicze, domagając się obniżenia opłat lotniskowych w zamian za uruchamianie nowych, atrakcyjnych połączeń (Ryanair). Do agresywnej polityki rozwoju tego typu firm należy również próba przejęcia narodowych linii Irlandii AerLingus, borykającej się z problemami finansowymi, przez głównego rywala z sektora tanich przewoźników: Ryanaira. Intensywna wojna cenowa przewoźników w krajach nadbałtyckich doprowadziła do upadku litewskich narodowych linii lotniczych FlyLAL w 2009 r. Linie lotnicze starają się przyciagnąć pasażerów, oferując dodatkowe usługi w cenie biletu, i tak np. w przypadku Turkish Airlines są to darmowe wycieczki po Istambule w przypadku dłuższego oczekiwania na połączenie przesiadkowe w tym mieście, Emirates natomiast proponuje pasażerom klasy biznesowej gratisowy nocleg w swoim głównym HUB-ie w Dubaju oraz podróż na lotnisko firmową limuzyną (obydwie usługi w przypadku dłuższego stop-overu). Podobne usługi wprowadził portugalski TAP (dla pasażerów lecących z Europy do Brazylii) oraz linie Air China w przypadku stop-overu na Tajwanie.

Bankructwa przewoźników to najbardziej drastyczny efekt pogłębiającego się kryzysu w branży.

Tab. 1. Bankructwa linii lotniczych w latach 2007-2010

\begin{tabular}{|l|c|c|l|}
\hline \multicolumn{1}{|c|}{ Nazwa linii } & Rok powstania & Rok bankructwa & \multicolumn{1}{|c|}{ Główny HUB } \\
\hline Maxjet Airways & 2003 & 2007 & Waszyngton \\
\hline Slovak Airlines & 1995 & 2007 & Bratysława \\
\hline ATA Airlines & 1973 & 2008 & Chicago \\
\hline Aloha Airlines & 1946 & 2008 & Honolulu \\
\hline Skybus Airlines & 2004 & 2008 & Port Columbus \\
\hline Eos Airlines & 2004 & 2008 & Nowy Jork \\
\hline Sun Country & 1982 & 2008 & Minneapolis \\
\hline Primaris Airlines & 2002 & 2008 & Las Vegas \\
\hline Sterling Airways & 1962 & 2008 & Kopenhaga \\
\hline Aviaprad & 1996 & 2008 & Jekaterynburg \\
\hline Futura Gael & 2007 & 2008 & Dublin \\
\hline Sky Europe & 2001 & 2009 & Bratysława \\
\hline
\end{tabular}




\begin{tabular}{|l|l|l|l|}
\hline Flyglobespan & 2003 & 2009 & Edynburg \\
\hline FlyLAL & 1991 & 2009 & Wilno \\
\hline Air Comet & 1996 & 2009 & Madryt \\
\hline Centralwings & 2004 & 2009 & Warszawa \\
\hline MyAir & 2004 & 2009 & Bergamo \\
\hline Seagle Air & 1995 & 2009 & Bratysława \\
\hline Arrow Air & 1947 & 2010 & Miami \\
\hline Mexicana & 1921 & 2010 & Meksyk \\
\hline Air Slovakia & 1993 & 2010 & Bratysława \\
\hline Cyprus Turkish Airlines & 1974 & 2010 & Nikozja \\
\hline Eurocypria Airlines & 1992 & 2010 & Larnaka \\
\hline
\end{tabular}

Źródło: opracowanie własne

W tabeli 1 przedstawiono listę linii lotniczych, które w latach 2007-2010 ogłosiły bankructwo. Zestawienie zawiera różne typy przewoźników zorientowane na zróżnicowane rynki: linie narodowe, takie jak Mexicana lub FlyLAL, typowe low-costy, do których należał SkyBus lub Centralwings oraz linie czarterowe, tj. Eurocypria lub Seagle Air. Warto wspomnieć, że upadłość ogłosiły również notujące największe w Azji przychody (i jednocześnie wielomiliardowe straty) japońskie linie lotnicze JAL. Ratunek przed wierzycielami i pomoc w spłacie długów przyniosło państwo. Głęboki plan restrukturyzacji przedsiębiorstwa polega między innymi na znacznym obniżeniu wielkości zatrudnienia, likwidacji nierentownych połączeń, a także wejście do sojuszu One World.

Mimo poważnych problemów, z jakimi w ostatnich latach borykają się towarzystwa lotnicze, można dostrzec wiele pozytywnych oznak w branży. Do nich z pewnością należy ekspansja na niespotykaną do tej pory skalę linii low-cost, której w Europie przewodzi irlandzki Ryanair. Przewoźnik co kilka miesięcy ogłasza inaugurację nowych baz (najnowsze, planowane na początek 2011 r., to Gran Canaria, Teneryfa i Lanzarote), w 2010 r. otwarto pierwszą w Europie Wschodniej bazę irlandzkiego giganta w litewskim Kownie. Wśród nowych krajów dodanych do siatki połączeń Ryanaira należy wymienić m.in. Estonię i Cypr. Prezentująca podobny model funkcjonowania linia easyJet poszerzyła swoją ofertę o nowe destynacje w Egipcie oraz Izraelu. Malezyjska Air Asia natomiast, oprócz rynku regionalnego, związanego przede wszystkim z krajami ASEAN, stawia również na połączenia dalekiego zasięgu. Ponadto poza na stałe już wpisanymi w rozkład lotów operacjami do Londynu czy Australii linia otwiera nowe trasy, m.in. do Paryża, irańskiego Teheranu czy też nowozelandzkiego Christchurch. Silną pozycję w branży mają również przewoźnicy bliskowschodni. Emirates, Qatar Airways to linie stale powiększające swoją flotę, zatrud- 
niające nowych pracowników. W Dubaju powstała także pierwsza w regionie tania linia lotnicza Flydubai.

\section{Podsumowanie}

Ostatnie lata charakteryzują się szeregiem zmian w światowym systemie gospodarczym, wynikających w dużej mierze z sytuacji kryzysowych na rynkach światowych. Transport lotniczy jest jednym z ogniw tego systemu, bardzo wrażliwym na wszelkiego rodzaju zmiany. Ze względu na trudną sytuację finansową, sektor ten odczuwa zmiany stosunkowo szybko. Przedstawiciele firm oraz prywatne osoby w sytuacji kryzysu finansowego bardzo szybko rezygnują z tego środka transportu, szczególnie na krótkich trasach. Głównym celem tego opracowania jest przedstawienie zmian w wielkości przewozów pasażerskich w największych portach lotniczych świata oraz wybranych kompaniach lotniczych. W pierwszej części opracowania zaprezentowano wielkość ruchu pasażerskiego na lotniskach przyjmujących największą liczbę podróżnych (Atlanta Hartsfield-Jackson, Londyn Heathrow, Frankfurt Intl.) w latach 2007-2010, czyli od momentu poprzedzającego ogólnoświatowy trend spadkowy w wielkości przewozów, aż do chwili obecnej (zgodnie z bieżącą dostępnością danych statystycznych). W następnej kolejności poddano analizie zmiany wielkości ruchu pasażerskiego $\mathrm{w}$ wybranych towarzystwach lotniczych operujących w różnych częściach świata, w podobnym do powyższego w czasie. $\mathrm{W}$ ostatnim fragmencie pracy autorzy starali się wskazać konkretne przykłady wpływu kryzysu w poszczególnych kompaniach lotniczych wraz ze sposobami walki firm o przywrócenie poziomu ruchu z okresu poprzedzającego kryzys.

\section{Literatura}

Radomyski A., 2009, Razem Łatwiej, „Air World”, nr 4 (9)

World Airport Traffic Report, 2007, Airports Council International

\section{The impact of the crisis on passenger's air traffic in the world on the basis of the selected examples}

Recent years have witnessed a whole range of changes in the global economic system; the changes have largely resulted from crisis situations in global markets. Air transport is an element of the system that is very sensitive to any kinds of changes. Due to a difficult financial situation the sector is relatively quickly affected. The corporate representatives and individuals in situation of financial crisis can easily resign from air transportation, especially for short distance travel. The main purpose of the paper is to present changes in passenger's air transport quantity in the largest airports of the world with respect to the selected air carriers. The first part of the article presents the size of passenger's air transport in the airports with the highest number of passengers (Atlanta Hartsfield-Jackson, London Heathrow, Frankfurt International) in years 2007-2010, i.e. since the moment preceding the global trend of decrease in air transportation till now (in accordance with the current availability of statistic data). Next, the changes in passenger's air transportation quantity for the selected air carriers operating 
in various parts of the world have been analyzed with respect to a comparable period of time. In the last part of the paper the authors tried to present the examples of the impact of crisis on particular air carriers as well as to discuss the attempts undertaken to restore the passenger's transportation rates to the level preceding the crisis.

dr Renata Rettinger

Uniwersytet Pedagogiczny w Krakowie

Instytut Geografii

Zakład Turystyki i Badań Regionalnych

e-mail: rettinger@onet.eu

mgr Piotr Staszak

Absolwent geografii Uniwersytetu Pedagogicznego w Krakowie 